\title{
Isolation and selection of rhizospheric bacteria with biofertilizing potential for corn cultivation
}

\author{
Vargas-Díaz, Arely A. ${ }^{1 *} ;$ Quintal-Vargas, Yaritza Y. ${ }^{2}$; Chale-Dzul Juan B. ${ }^{3}$, Santillán-Fernández, Alberto ${ }^{1}$; \\ Ferrera-Cerrato, Ronald ${ }^{4}$, López-Hernández, Mónica B. ${ }^{2}$
}

\begin{abstract}
${ }^{1}$ CONACyT-Colegio de Postgraduados, Campus Campeche, Champotón, Carretera HaltunchénEdzná km 17.5, Sihochac, Champotón, Campeche, México. ${ }^{2}$ Instituto Tecnológico de Chiná, San Francisco de Campeche, Calle 11 s/n entre 22 y 28 Chiná, Campeche, Campeche, México. ${ }^{3}$ Hospital de especialidades 1 Centro Médico Nacional Ignacio García Telléz del IMSS. C 41 N 436 Colonia industrial ex terrenos el fénix, Mérida Yucatán, México. ${ }^{4}$ Colegio de Postgraduados, Posgrado de Edafología. Campus Montecillo, Texcoco, México.
\end{abstract}

*Corresponding Author: anayansi.3185@gmail.com

\section{ABSTRACT}

Objective: To isolate and determine in a greenhouse environment the biofertilizing potential of rhizospheric bacteria associated to corn (Zea mays L.) at Campeche, Mexico.

Design/methodology/approach: Rhizospheric soils were collected from two corn production zones with different management conditions. Bacterial strains were isolated from these samples and their biofertilizing potential determined by in vitro and in vivo tests. The obtained data from both tests were assessed using an analysis of variance (ANOVA) and a means comparison test (LSD, $\mathrm{p} \leq 0.01$ ).

Results: In total, 16 rhizospheric bacteria were isolated, a higher number in non-mechanized soils $(n=10)$ compared to mechanized ones $(n=6)$. In the in vitro tests, the most representative activity corresponds to nitrogen fixation (81\%) attributed to a higher bacteria percentage, while the activity with lower bacteria numbers corresponds to IAA production (25\%). At the in vivo tests in corn plants, the YM1 strain presented the highest fresh and dry root biomass (20 and $2 \mathrm{~g}$ plant $^{-1}$, respectively). The YM4 strain promoted greater plant height $(63.33 \mathrm{~cm})$, and YM5 registered the highest values in stem diameter $(7.13 \mathrm{~mm})$, root length $(36.78 \mathrm{~cm})$ and fresh shoot weight $\left(12.03 \mathrm{~g} \mathrm{plant}^{-1}\right)$.

Limitations/Implications: Strain evaluations were limited to controlled greenhouse conditions.

Conclusion: The YM1, YM4 and YM5 strains show potential for further evaluation as biofertilizers for corn cultivation under field conditions.

Keywords: sustainable strategies, plant growth, biofertilization.

\section{INTRODUCTION}

C (Zea mays L.) is considered the most important cereal in the world (Kurtz et al., 2016). In Mexico it is million hectares and a production volume of 23 million tons. Despite this, its national demand is around 39 million tons, so there is a production deficit (FAOSTAT, 2020; Reyes et al., 2018). Given this situation, it is important to increase corn's

Agroproductividad: Vol. 14, Núm. 1, enero. 2021. pp: 69-73 
national production. However, this crop is highly extractive of the soil and therefore usually receives chemical fertilization, which represents $40-50 \%$ of their production cost and results in a lower profit margin for their producers (Reyes et al., 2018). The periodic use of fertilizers affects the environment and human wellbeing (Olanrewaju and Babalola, 2019). For this reason, it is important to investigate environmentally friendly production alternatives. In this sense, the bacteria found in the region around the plant's root systems are also known as plant growth-promoting rhizobacteria (PGPR) can be a strategy (Olanrewaju and Babalola, 2019). These bacteria can promote plant growth through various mechanisms, such as biological nitrogen fixation, and phosphorus, potassium, and some micronutrients solubilization, as well as promoting phytohormones synthesis and other metabolites associated with pathogens biocontrol such as antibiotics and siderophores. (Olanrewaju et al., 2017). There are several reports of groups of rhizobacteria associated with corn that promote its growth (Abedinzadeh et al., 2019; Bjelić et al., 2018; Karnwal, 2017; Richard et al., 2018; Toribio-Jiménez et al., 2017); however, native microorganisms may be better adapted to a specific region, making them ideal in strain selection processes, given that they could be more competitive than introduced bacteria (Karagöz, 2012). In this regard, even though in the state of Campeche, Mexico, corn is the main cultivated grain, with an area of approximately 150 thousand hectares (SAGARPA, 2019), there are no reports of native rhizobacteria used in its cultivation. Based on the above, the present work aims to isolate and determine in a greenhouse environment the biofertilizing potential of rhizospheric bacteria associated to corn (Zea mays L.) at Campeche, Mexico.

\section{MATERIALS AND METHODS}

The samples were collected from corn rhizospheric soil with different management conditions. At the ejido El Poste, Hopelchén, Campeche $\left(19^{\circ}\right.$ $52^{\prime} 12^{\prime \prime} \mathrm{N}$ and $89^{\circ} 52^{\prime} 16^{\prime \prime} \mathrm{W}$ ) the samples considered as mechanized soil were

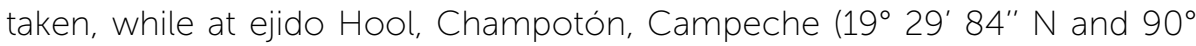
$26^{\prime}$ 03" W) the non-mechanized soil samples. The rhizospheric soils were collected at a 0-20 cm depth, sampling five subsamples (golden five) that formed a composite sample. The soil was dried at room temperature for two days, sieved and stored in refrigeration until its microbiological analysis. The bacteria isolation was carried out via serial dilutions on base 10 following the methods by Velázquez-Gurrola et al. (2015). For this, $10 \mathrm{~g}$ of rhizospheric soil were diluted in $90 \mathrm{~mL}$ sterile water, up to 1/107. The specific solid media used were Pikovskaya and Rennie at $28^{\circ} \mathrm{C}$ incubation. The different colonies were isolated and purified by exhaustion streak. The isolated strains were macroscopically characterized by polyphasic taxonomy and microscopically by Gram stain (Vincent and Humphrey, 1970). Likewise, the catalase test was performed (Hayward, 1960).

In vitro plant growth promotion was determined by inoculating $20 \mu \mathrm{L}$ of each isolated strain in different specific media. The growth of the strain in Rennie medium indicates its nitrogen-fixing ability (Rennie, 1981). The phosphorus solubilization was determined in Pikoskaya agar medium as described by Ramírez et al. (2014). Potassium solubilization was determined with a modified Pikoskaya medium following Velázquez-Gurrola et al. (2015).
Organic acid production was determined as described by Ogale et al. (2018). The phosphorus or potassium solubilization index (PSI or KSI) was calculated as the PSI or $\mathrm{KSI}$ ratio= (zone of halo+colony diameter)/colony diameter (Ramírez et al., 2014.). The production of indole-3-acetic acid (IAA) was determined as described by Sarker and Al-Rashid (2013) using Salkowaski reagent. The strains were grown in liquid Luria Bertani (LB) media and Nutritive Broth (NB) (given the bacteria requirement) with tryptophan (0.1\%). The supernatant was used for AIA quantification with the aid of a Spectroquant NOVA60 spectrophotometer at a $540 \mathrm{~nm}$ length. The indole compound concentration was calculated with a linear regression equation of the calibration curve constructed with known IAA concentrations.

The in vivo growth promotion determination in corn plants was carried out in a greenhouse at the Campus Campeche of the Colegio de Postgraduados (19 49' 79" N; $90^{\circ} 54^{\prime} 76^{\prime \prime} \mathrm{W}$ ). For it, the strains were selected and named as YM1, YM3, YM4, YM5 and for their effect in the in vitro tests. Bacteria were grown for five days in LB or CN media in an incubator (Thermo scientific MAXQ 4450) with shaking at $150 \mathrm{rpm}$ at 28 ${ }^{\circ} \mathrm{C}$. The cultures were centrifuged at $4000 \mathrm{rpm}$ and the inoculants were prepared at a $10^{8} \mathrm{CFU} \mathrm{\textrm {mL } ^ { - 1 }}$ concentration from the bacterial cell pellet. Corn seeds of the Dekalb 410 variety were disinfected with sodium hypochlorite (2\%) and ethanol (96\%) and placed in Petri dishes with sterile filter paper for 7 days until germination. Later, the plants were transplanted placing one plant per pot with a sterile substrate (earth, perlite and Peat 
moss). After $3 \mathrm{~d}$, the plants were inoculated with $1 \mathrm{~mL}$ of the bacteria. In total, six treatments were evaluated in a completely randomized experimental design with five repetitions, these corresponded to: T1) control (with no inoculation), T2) inoculation with the YM1 strain, T3) inoculation with the YM3 strain, T4) inoculation with the YM4 strain, 5) inoculation with strain YM5 and T6) inoculation with strain YM6. Thirty days after inoculation, the following variables were assessed: Plant height (PH), stem diameter (SD), root length ( $R L)$, stem fresh weight (SFW), stem dry weight (SDW), fresh root weight (FRW) and root dry weight (RDW). The data obtained in the in vitro and in vivo tests were analyzed in the SAS statistical software for Windows version 9, through an analysis of variance (ANOVA) and comparison test of means (LSD, $p \leq 0.01$ ) (Steel and Torrie, 1986).

\section{RESULTS AND DISCUSSION}

In total 16 rhizospheric bacteria were isolated from corn soil subjected to different management conditions. A higher number of bacteria was isolated from nonmechanized soil from the ejido of Hool, Champotón, Campeche $(n=10)$. A lower number, from mechanized soil from the ejido Poste, Hopelchén, Campeche $(n=6)$ (Table 1). This can be explained, excessive mechanization has been documented to affect soil quality and the development of beneficial microorganisms (Padron et al., 2012).

From the total isolates, 62.5\% (10 strains) were Grampositive, the remaining Gram-negative (Table 1). Similarly, Toribio-Jiménez et al. (2017) and Abedinzadeh et al. (2019) reported a higher number of Gram-positive in corn. The $56 \%$ of the isolated strains were aerobic or catalase-positive, similar to those reported by Karnwal (2017).

Regard the in vitro plant growth promoter potential of the isolated strains, a nitrogen-fixing bacteria predominance (81\%) was observed (Table 1). These results concur with reports of rhizospheric soils from corn (Toribio-Jiménez et al., 2017; Karnwal, 2017, Richard et al., 2018). In the production of indoloacteic acid (IAA), only $25 \%$ of the strains had this activity, the statistical analysis determined significant differences between them. The YRC2 strain reported the highest IAA production (4.264 $\mu \mathrm{g} \mathrm{mL}^{-1}$ ) registering statistical differences regard to the GRC4 $\left(1.739 \mu \mathrm{g} \mathrm{mL}^{-1}\right)$, YM6 $\left(0.526 \mu \mathrm{g} \mathrm{mL}^{-1}\right)$ and YM4 (0.736 $\mu \mathrm{g}$ $\mathrm{mL}^{-1}$ ) strains. Olanrewaju and Babalola (2019) reported similar percentages in the number of bacteria capable of producing IAA in corn (20\%). Similarly, the IAA production values found in the bacteria in this study were similar to those previously reported in bacteria obtained from rhizospheric soil of corn (0.10 to $3.6 \mu \mathrm{g} \mathrm{mL}^{-1}$ ) (Mehnaz et al., 2010).

Respect phosphorus solubilization, $56 \%$ of the strains reported this activity. The statistical analysis of the phosphorus solubilization index (PSI) showed statistically significant differences between the strains. The GPA2 $(0.453 \mathrm{~mm})$ and YM1 $(0.426 \mathrm{~mm})$ strains had the highest ISP with no statistical difference between both. The YM6 (0.386 mm), YPB2 (0.363 mm) and YM3 (0.346 mm) strains had a medium activity PSI (Table 1). Olanrewaju and Babalola, (2019) reported a lower phosphorus solubilizing bacteria percentage in corn rhizospheric soil $(29 \%)$, of which three reported medium and seven had slight activity.

Regard the potassium solubilization, 31\% of the strains reported this capacity; however, no statistical significance was observed (Table 1). The main mechanism of potassium and phosphorus solubilization in bacteria is by organic and inorganic acids production (acidolysis) (Meena et al., 2014; Paredes-Mendoza and EspinosaVictoria, 2010), in this study the high number of bacteria capable of producing organic acids (50\%) suggests this is an important mechanism used by bacteria isolated from corn.

In the in vivo greenhouse plant growth promotion tests, statistical differences were observed in the assessed variables between the evaluated treatments. Plants treated with $\mathrm{T} 4$ (YM4) $(63.33 \mathrm{~cm})$ showed a higher $\mathrm{PH}$ (Table 2). This strain can produce IAA in vitro, as this auxin has regulatory effects on the growth and development of plants (Vessey, 2003), it could explain its effect on the PH variable. In turn, T5 treatment (YM5) reports the highest $\mathrm{SD}(7.13 \mathrm{~mm}), \mathrm{RL}(36.78 \mathrm{~cm})$ and SFW (12.03 g per plant). Also, the T2 (YM1) treatment showed the highest RDW (20.00 g per plant) and RDW (2.01 g per plant) (Table 2).

The data obtained on the root and shoot dry weight were higher than those previously reported from two corn varieties due to the application of Pseudomonas putida (CR7) and Sphingobacterium canadense CR11 bacteria (Mehnaz et al., 2010). The YM1 and YM5 strains in vitro showed nitrogen fixation ability, organic acids production, and phosphorus and potassium solubilization. In this regard, it has been reported that nitrogen promotes rapid 
Table 1. Biochemical and physiological properties involved in plant growth-promoting of bacterial strains isolated from two sites at the state of Campeche, Mexico.

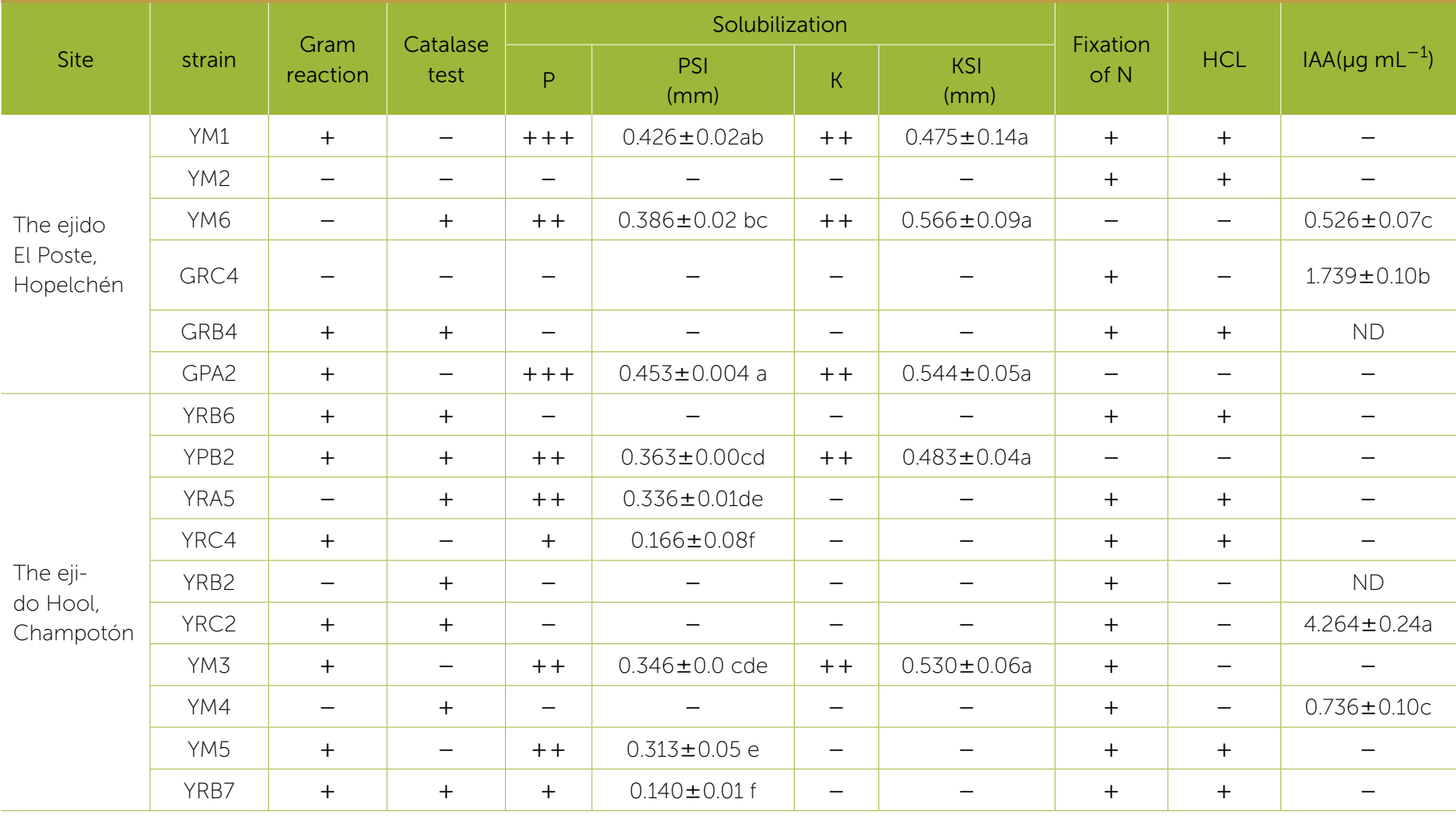

+ : positive activity, - : negative activity, +++ : high production, ++ : medium production, + : low production; PSI $=$ phosphorus solubilization index, KSI = potassium solubilization index. HCL: production of organic acids, ND: not determined. IAA: production of indoleacetic acid. Means with same letters within each column are not statistically different (LDS, 0.05).

\begin{tabular}{|c|c|c|c|c|c|c|c|}
\hline T2:YM1 & $61.15 \pm 0.8 \mathrm{ab}$ & $6.63 \pm 1.1 \mathrm{ab}$ & $33.40 \pm 1.2 \mathrm{ab}$ & $11.12 \pm 2.3 a b$ & $1.63 \pm 0.3 a b$ & $20.00 \pm 0.0 \mathrm{a}$ & $2.01 \pm 0.1 \mathrm{a}$ \\
\hline T5: YM5 & $60.90 \pm 1.0 a b$ & $7.13 \pm 1.0 \mathrm{a}$ & $36.78 \pm 4.3 a$ & $12.03 \pm 3.8 a$ & $1.90 \pm 0.6 a b$ & $17.12 \pm 1.3 b$ & $1.81 \pm 0.2 \mathrm{ab}$ \\
\hline T6: YM6 & $59.37 \pm 0.3 b$ & $5.80 \pm 0.9 b$ & $28.67 \pm 2.0 \mathrm{~cd}$ & $11.60 \pm 0.7 a b$ & $1.30 \pm 0.1 b$ & $10.98 \pm 0.8 c$ & $1.27 \pm 0.1 d$ \\
\hline
\end{tabular}

$\mathrm{PH}$ : Plant height, $\mathrm{SD}=$ stem diameter; $\mathrm{RL}=$ root length; SFW = stem fresh weight; SDW: stem dry weight, RFW: root fresh weight, RDW = root dry weight. Means $(n=10)$ with the same letters in each column are not statistically different $(L S D, 0.05) . \pm=$ standard deviation.

cell division and elongation (Peña and Reyez, 2007) coupled with the fact that phosphorus is an important micronutrient for plant growth since it participates in multiple metabolic processes (Karnwal, 2017). Viruel et al. (2014) demonstrated that phosphorus solubilizing bacteria can stimulate stem growth and higher biomass production.

The results indicate that the YM1, YM4 and YM5 rhizobacteria have positive effects on growth promotion of corn plants and therefore have great potential to be used in the field as biofertilizers in this study region.

\section{CONCLUSION}

Sixteen bacteria strains were isolated and a greater number of strains from non-mechanized soils. The plant growth promoter activity with the highest percentage of bacteria corresponded to nitrogen fixation. The lowest activity corresponded to IAA production. YM1, YM4 and YM5 strains showed a positive effect in promoting plant 
growth of corn plants in in vivo tests. Therefore, they show the potential to be evaluated as biofertilizers for corn cultivation under field conditions.

\section{ACKNOWLEDGEMENTS}

We thank the Consejo Nacional de Ciencia y Tecnología for its support to the Cátedra CONACyT 364 project.

\section{REFERENCES}

Abedinzadeh, M., Etesami, H., \& Alikhani, H. A. (2019). Characterization of rhizosphere and endophytic bacteria from roots of maize (Zea mays L.) plant irrigated with wastewater with biotechnologica potential in agriculture. Biotechnology Reports 21: e00305 DOI: 10.1016/j.btre.2019.e00305

Bjelić, D., Marinković, J., Tintor, B., \& Mrkovački, N. (2018). Antifungal and plant growth promoting activities of indigenous rhizobacteria isolated from maize (Zea mays L.) rhizosphere. Communications in Soil Science and Plant Analysis 49(1): 8898. DOI: 10.1080/00103624.2017.1421650

FAOSTAT (The Food and Agriculture Organization Corporate Statistical Database). (2020). Disponible en http://www.fao.org/faostat/ es/\#data. Consultado en enero de 2020

Hayward, A.C. (1960). A method for characterizing Pseudomonas solanacearum. Nature, 186: 405-406.

Karagöz, K., Ateş, F., Karagöz, H., Kotan, R., \& Çakmakçı, R. (2012) Characterization of plant growth-promoting traits of bacteria isolated from the rhizosphere of grapevine grown in alkaline and acidic soils. European Journal of Soil Biology 50: 144-150 DOI: 10.1016/j.ejsobi.2012.01.007

Karnwal, A. (2017). Isolation and identification of plant growth promoting rhizobacteria from maize (Zea mays L.) rhizosphere and their plant growth promoting effect on rice (Oryza sativa L.). Journal of Plant Protection Research 57(2): DOI: 10.1515/ jppr-2017-0020

Kurtz, B., Gardner, C. A., Millard, M. J., Nickson, T., \& Smith, J. S. C. (2016). Global access to maize germplasm provided by the US National Plant Germplasm System and by US plant breeders. Crop Science 56(3): 931-941. DOI: 10.2135/cropsci2015.07.0439

Mehnaz, S., Kowalik, T., Reynolds, B., \& Lazarovits, G. (2010). Growth promoting effects of corn (Zea mays) bacterial isolates under greenhouse and field conditions. Soil Biology and Biochemistry, 42(10): 1848-1856. DOI: 10.1016/j.soilbio.2010.07.003.

Ogale, S., Yadav, K. S., \& Navale, S. (2018). Screening of endophytic bacteria from the pharmacologically important medicinal plant Gloriosa superba for their multiple plant growth promoting properties. The Pharma Innovation Journal 7: 208-214.

Olanrewaju, O. S., \& Babalola, O. O. (2019). Bacterial Consortium for Improved Maize (Zea mays L.) Production. Microorganisms 7(11): 519. DOI: 10.3390/microorganisms7110519

Olanrewaju, O.S., Glick, B.R., Babalola, O.O. (2017). Mechanisms of action of plant growth promoting bacteria. World Journal Microbiology and Biotechnology 33(11): 197. DOI: 10.1007/ s11274-017-2364-9

Padron, L., Torres Rodriguez, D. G., Contreras Olmos, J., López, M., \& Colmenares, C. (2012). Aislamientos de cepas fijadoras de nitrógeno y solubilizadoras de fósforo en un suelo alfisol venezolano. Revista mexicana de ciencias agrícolas 3(2): 285-297

Paredes-Mendoza, M., \& Espinosa-Victoria, D. (2010). Ácidos orgánicos producidos por rizobacterias que solubilizan fosfato: una revisión crítica. Terra Latinoamericana 28(1): 61-70.

Peña, H. \& Reyes, I. (2007). Aislamiento y evaluación de bacterias fijadoras de nitrógeno y disolventes de fosfatos en la promoción del crecimiento de la lechuga (Lactuca sativa L.). Interciencia 32(8): $560-565$

Pikovskaya, R. I. (1948). Mobilization of phosphorus in soil in connection with the vital activity of some microbial species. Microbiology 17: $362-370$

Ramírez, L. C. C., Leal, L. C. S., Galvez, Z. Y. A., \& Burbano, V. E. M. (2014). Bacillus: género bacteriano que demuestra ser un importante solubilizador de fosfato. Nova 12(22). 165-177. DOI $10.22490 / 24629448.1041$

Rennie, R. J. (1981). A single medium for the isolation of acetylenereducing (dinitrogen-fixing) bacteria from soils. Canadian Journal of Microbiology 27(1): 8-14

Reyes, L. M., Jiménez, C. E. A., Montiel, M. G. C., Galdámez, J. G., Cabrera, J. A. M., Aguilar, F. B. M., ... \& Padilla, E. G. (2018) Biofertilización y fertilización química en maíz (Zea mays l.) en Villaflores, Chiapas, México. Siembra 5(1): 026-037.

Richard, P. O., Adekanmbi, A. O., \& Ogunjobi, A. A. (2018). Screening of bacteria isolated from the rhizosphere of maize plant (Zea mays L.) for ammonia production and nitrogen fixation. African Journal of Microbiology Research 12(34): 829-834. DOI: 10.5897/ajmr2018.8957

SAGARPA. (2015). Maiz de temporal. Agenda Técnica Agrícola de Campeche, pp.87.

Sarker, A., \& Al-Rashid, J. (2013) Analytical protocol for determination of Indole 3 acetic acid (IAA) production by Plant Growth Promoting Bacteria (PGPB). Technical report of Quantification of IAA by microbes, pp 1-2

Steel, R. D.G., \& Torrie, J. H. (1986). Bioestadística. Principios y procedimientos. 2 da edición Ed. Mc Graw-Hill, México D.F. $622 \mathrm{pp}$.

Toribio-Jiménez, J., Rodríguez-Barrera, M. Á., Hernández-Flores, G., Ruvacaba-Ledezma, J. C., Castellanos-Escamilla, M., \& Romero-Ramirez, Y. (2017). Isolation and screening of bacteria from Zea mays plant growth promoters. Revista Internaciona de Contaminación Ambiental 33: 143-150. DOI: 10.20937/ RICA.2017.33.esp01.13

Velázquez-Gurrola, A., \& Ramos-Alegría, M. P. (2015). Beneficios de microorganismos solubilizadores de $\mathrm{P}$ y $\mathrm{K}$ en la recuperación y mantenimiento de suelos agrícolas. LIMA, PERU, Perú ProHass, 495-499.

Vessey, J. K. (2003). Plant growth promoting rhizobacteria as biofertilizers. Plant and soil 255(2): 571-586. DOl: 10.1023/a:1026037216893

Vincent, J.M., \& Humphrey, B. (1970). Taxonomically significant group antigens in Rhizobium. Microbiology 63(3): 379-382.

Viruel, E., Erazzú, L. E., Martínez Calsina, L., Ferrero, M. A., Lucca, M. E., \& Siñeriz, F. (2014). Inoculation of maize with phosphate solubilizing bacteria: effect on plant growth and yield. Journal of soil science and plant nutrition 14(4): 819-831. DOI: 10.4067/ S0718-95162014005000065 